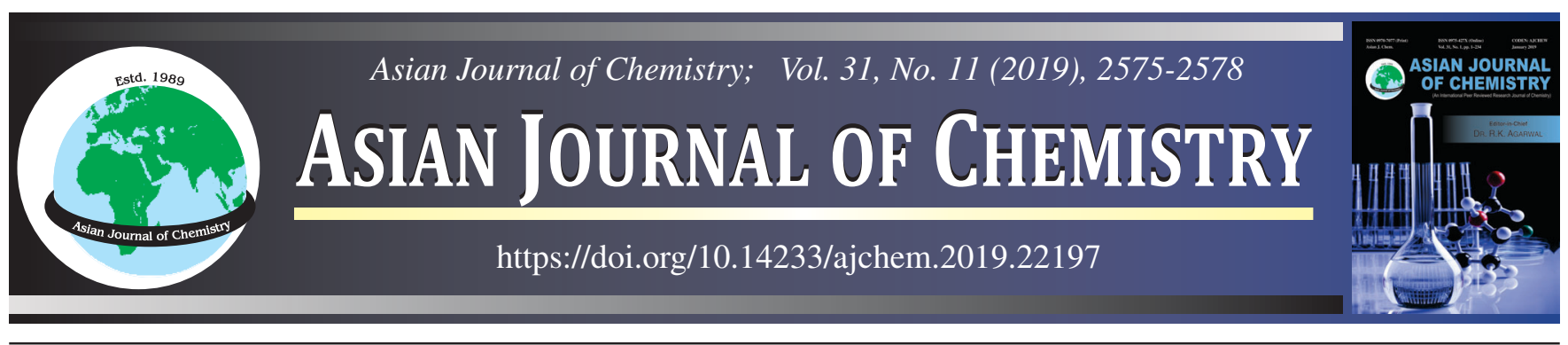

\title{
Progressive Two-Stage Efficient Codigestion of Food Waste and Petrochemical Wastewater for Higher Methane and Hydrogen Production
}

\author{
M.N.I. SIDDIQUE ${ }^{1, *}$, B.K. ZAIED ${ }^{2}$, M.N. KABIR ${ }^{3}$ and M.F. AHMAD ${ }^{1}$
}

${ }^{1}$ School of Ocean Engineering, Universiti Malaysia Terengganu, 21030 Kuala Nerus, Terengganu, Malaysia

${ }^{2}$ Faculty of Engineering Technology, Universiti Malaysia Pahang, 26300 Gambang, Kuantan, Pahang, Malaysia

${ }^{3}$ Faculty of Computer System and Software Engineering, Universiti Malaysia Pahang, 26300 Gambang, Kuantan, Pahang, Malaysia

*Corresponding author: Fax: +60 9 5493006; Tel.: +60 9 6683614; E-mail: m.nurul@umt.edu.my

Received: 13 May 2019;

Accepted: 3 July 2019;

Published online: 28 September 2019;

AJC-19588

The valorization of agro-modern waste through anaerobic codigestion signifies a remarkable prospect for waste treatment and sustainable energy source generation. This study intended to improve the codigestion of food waste and petrochemical wastewater by an advanced two-phase process. In view of concentric acidogenic and methanogenic stages, intended for upgrading execution and diminishing pollution. The ideal food waste to petrochemical wastewater proportion was assessed under batch operations. From that point, codigestion was carried out by continuous feeding operations weighting single-and two-phase digestions. The outcomes exhibited that the supplementation of petrochemical wastewater in codigestion with food waste incredibly improved the anaerobic system. The maximum methane generation was acquired codigesting the two wastes at equivalent proportion by utilizing the creative two-phase system. The proposed framework achieved the highest methane production of $259 \mathrm{~mL} / \mathrm{g}$ volatile solid, which is more than double than the single-phase system and $11 \%$ greater than that of conventional two-phase system.

Keywords: Methane, Anaerobic codigestion, Petrochemical wastewater, Food waste.

ᄂ _ - - - - - - - - - - - - - - - - - - - - - - - - - - - -

\section{INTRODUCTION}

The best possible management and valorization of agroindustrial effluents through anaerobic systems offers a substantial prospect to pollution control and sustainable energy source generation [1]. Food waste is the fundamental output of food business [2]. It is categorized by an extremely high organic matters and low buffering capacity; subsequently, anaerobic codigestion of food waste can prompt fast fermentation that produces lower biogas profitability [3].

During petrochemical wastewater anaerobic digestion, huge amount of volatile fatty acid is produced which is inhibitory to methane production [4]. A few investigations have exhibited that cofermentation of food waste with petrochemical waste-water may keep up ideal $\mathrm{pH}$ and increase biogas generation [5], yet the ideal substrate proportion and the hypothetical gas generation varies in every particular case.

Anaerobic digestion is chosen in light of the fact that food waste typically shows high fermentation potential and needs longer HRT, and due to the little scale and disintegration of food processing industries. In course of the most recent decade, different bioreactor arrangements had been assessed and suggested for biogas enhancement from wastes [6]. Easy design frameworks experience less operational difficulties, and produces economic advantages in planning, development and executions. However, codigestion and two-phase digesters provides high treatment ability and system balance than the individual fermentation and the utilization of single-phase systems [7].

This investigation intended to build up an advanced twophase process dedicated to the cofermentation of food waste and petrochemical wastewater that may combine the benefits of the traditional procedures with the high productivity of multiphase digesters. Therefore, a continuous two-phase process was established so that first acidogenic phase was introduced into the methanogenic digester with a concentric structure (Fig. 1). From our perspective, this is the latest study to increase the codigestion of food waste and petrochemical wastewater by assessing distinctive designs.

This is an open access journal, and articles are distributed under the terms of the Attribution 4.0 International (CC BY 4.0) License. This license lets others distribute, remix, tweak, and build upon your work, even commercially, as long as they credit the author for the original creation. You must give appropriate credit, provide a link to the license, and indicate if changes were made. 


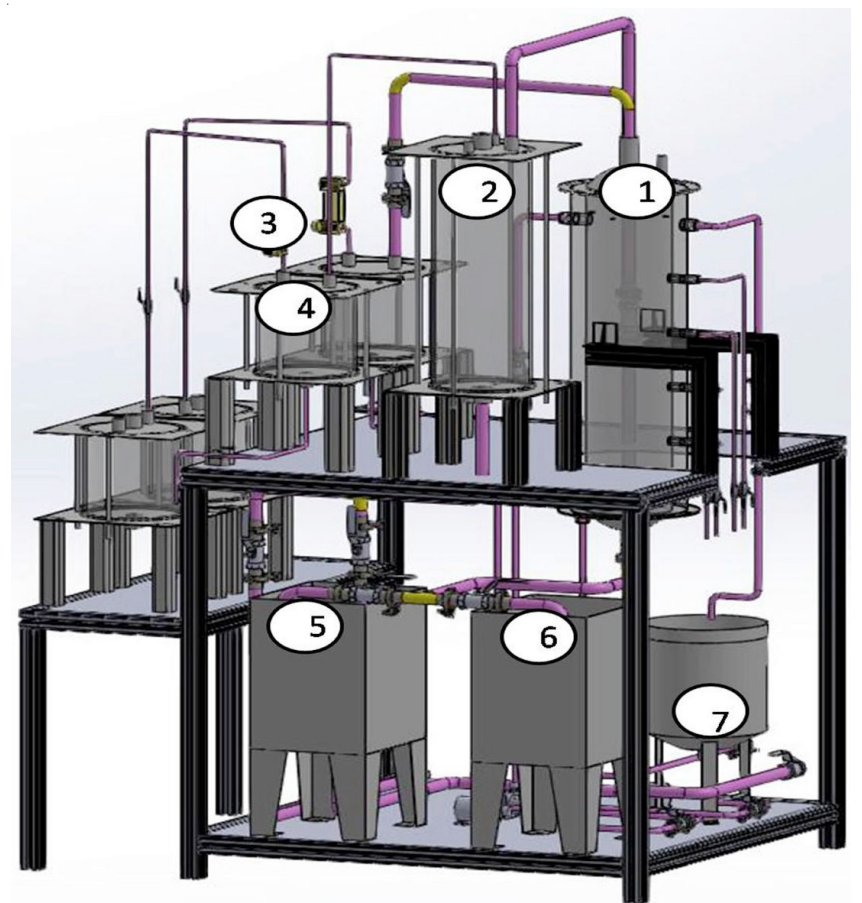

Fig. 1. Laboratory scale experimental digester setup where: (1) Singlephase digester (2) Two-phase digester (3) gas meter with gas collection tank (4) Two-phase concentric digester (5) Outlet of twophase digester (6) Inlet of two-phase and two-phase concentric digester (7) Inlet of single-phase digester

\section{EXPERIMENTAL}

Substrates and inoculum: The agro-industrial wastes utilized as (W) influent wastewater for the anaerobic degradation experiments were food wastes (IFW) and petrochemical wastewater (IPWW), food wastes were acquired from a restaurant of University Malaysia Terengganu, Malaysia and petrochemical wastewater was collected from Petronas Penapisan (Terengganu) Sdn. Bhd., Terengganu, Malaysia.

Three individual inoculum were experimented as seedsludge for the anaerobic degradation tests. They comprised of methanogenic microbs from a palm oil mill (POM) effluent gathered from a palm oil mill situated in Kuantan (Malaysia), petrochemical wastewater sludge $\left(\mathrm{I}_{\mathrm{PWw}}\right)$ and sludge from a anaerobic digester $\left(\mathrm{I}_{\mathrm{D}}\right)$ treating municipal wastewater as reported by Siddique and Wahid [8]. The fundamental properties of substrates and inoculum are listed in Table-1.

Batch experiments: Batch tests were done as fundamental examination to distinguish the ideal working conditions for codigestion to be used in the continuous digesters. The methanogenic performance of wastes was estimated by biochemical methane potential (BMP) method [8]. The tests were led in triplicate in $100 \mathrm{~mL}$ containers by including $5 \mathrm{~mL}$ of inocula and $50 \mathrm{~mL}$ of wastewater comprising of codigestion waste blends. The containers were kept under $37^{\circ} \mathrm{C}$. The observations were done until full methane generation reduction (up to hundred days).

Three arrangement of batch test were carried out. The initial experiment was led to assess the effect of the three inoculum $\left(\mathrm{I}_{\mathrm{FW}}, \mathrm{I}_{\mathrm{PWw}}\right.$ and $\left.\mathrm{I}_{\mathrm{D}}\right)$ on the two substrates $\left(\mathrm{W}_{\mathrm{FW}}\right.$ and $\left.\mathrm{W}_{\mathrm{PWw}}\right)$ used in codigestion (in equivalent volume proportions). Subsequent biochemical methane potential (BMP) experiment was done to distinguish the ideal blend proportion of two substrates utilizing $\mathrm{I}_{\mathrm{D}}$ as inoculum; hence, two substrates were processed at various $\mathrm{I}_{\mathrm{FW}}$ : $\mathrm{I}_{\mathrm{PWw}}$ proportions varying from 0 to $100 \% \mathrm{v} / \mathrm{v}$ with a regular interval of $10 \%$ increment. The third arrangement of batch experiments planned to assess the ideal acidogenic states to begin the two-phase system. The examinations were carried out for the momentary biochemical hydrogen potential (BHP) test with trivial changes [9]. In contrast to BMP tests, the $\mathrm{pH}$ was first maintained to $6.1 \pm 0.4 \mathrm{using} \mathrm{HCl}$ to increase the acidogenesis. The experiments went on for about 14 days and stopped when methane was seen in the biogas. The digesters were run with 50:50- $\mathrm{W}_{\mathrm{FW}}: \mathrm{W}_{\mathrm{Pww}}$ volumetric proportion. The acidogenesis was measured at room temperature $\left(22^{\circ} \mathrm{C}\right)$ and mesophilic $\left(37^{\circ} \mathrm{C}\right)$ states. The batch experiments were observed weekly.

Continuous codigestion: The experiments were done utilizing three laboratory-scale digesters, where one-and twophase systems were set. The one-phase system was performed in a totally blended digester (D1, Fig. 1). The two-phase system was performed utilizing two distinct plans: in the primary design (D2), a second tiny totally blended reactor was included prior to the methanogenic container (Fig. 1). The second twophase digester (D3) comprised of a solitary vessel that involved both the acidogenic and the methanogenic phases. The previous was concentrically incorporated into the subsequent with the goal that the fermented effluent was fed by gravity at methanogenic phase (Fig. 1).

The methanogenic digester had a capacity of $600 \mathrm{~mL}$ for $\mathrm{D} 1$ and D2, and $800 \mathrm{~mL}$ for D3; the acidogenic stage had a capacity of 130 and $200 \mathrm{~mL}$ in D2 and D3, individually. Each digester were fed by feeding pumps. A 21 days HRT was maintained for methanogenic stage and 6 days of HRT was maintained for acidogenic stage. Organic loading rate of 1.9 and $1.8 \mathrm{~kg} \mathrm{COD} \mathrm{m}^{3} / \mathrm{d}$ for the one-and two-phase digester was maintained, individually. Based on the outcomes acquired by batch tests, the digesters were seeded by anaerobic sludge ID and operated under equal substrate proportion of 50:50 (WPWW: WFW).

TABLE-1

PROPERTIES OF FEED WASTEWATER AND INOCULUM (AVERAGE \pm SD) $\left(\mathrm{W}_{\mathrm{FW}}: \mathrm{W}_{\mathrm{PWW}}=50: 50\right)$

\begin{tabular}{lcccccc}
\hline \multicolumn{1}{c}{ Parameters } & Inoculum $\mathrm{I}_{\mathrm{POME}}$ & $\mathrm{I}_{\mathrm{PWW}}$ & $\mathrm{I}_{\mathrm{D}}$ & Wastewater $_{\mathrm{FW}}$ & $\mathrm{W}_{\mathrm{PWW}}$ & $\mathrm{Influent}_{\mathrm{Feed}}$ \\
\hline Density $(\mathrm{g} / \mathrm{mL})$ & $1.01 \pm 0.02$ & $1.07 \pm 0.03$ & $1.03 \pm 0.02$ & $1 \pm 0.1$ & $1 \pm 0.1$ & - \\
$\mathrm{pH}$ & $5 \pm 0.1$ & $4 \pm 0.1$ & $5 \pm 0.1$ & $4.98 \pm 0.1$ & $6.81 \pm 0.1$ & $6.8 \pm 0.1$ \\
$\mathrm{COD}(\mathrm{g} / \mathrm{L})$ & $22 \pm 2$ & $13 \pm 2$ & $23 \pm 3$ & $59 \pm 2$ & $9.6 \pm 0.2$ & $36 \pm 7$ \\
Carbohydrates $(\mathrm{g} / \mathrm{L})$ & - & - & - & $43 \pm 3$ & $1.5 \pm 0.4$ & $12 \pm 5$ \\
Proteins $(\mathrm{g} / \mathrm{L})$ & - & - & - & $1.5 \pm 0.5$ & $0.5 \pm 0.2$ & $0.9 \pm 0.2$ \\
Total solids $(\mathrm{g} / \mathrm{L})$ & $12 \pm 0.1$ & $24.1 \pm 5$ & $32 \pm 4$ & $58 \pm 9$ & $26 \pm 0.2$ & $36.4 \pm 3$ \\
Volatile solids $(\mathrm{g} / \mathrm{L})$ & $5 \pm 0.2$ & $13 \pm 3$ & $15 \pm 2$ & $53 \pm 8$ & $18 \pm 0.2$ & $30.5 \pm 4$ \\
Density $(\mathrm{g} / \mathrm{mL})$ & $1.01 \pm 0.02$ & $1.07 \pm 0.03$ & $1.03 \pm 0.02$ & $1 \pm 0.1$ & $1 \pm 0.1$ & - \\
\hline
\end{tabular}


The laboratory scale digesters were operated under mesophilic state at $37^{\circ} \mathrm{C}$. Prior to beginning the analyses, the digesters were run for roughly one month so as to adapt the biomass to the substrate. The digesters were run for over two months and their execution was assessed under steady states.

Analysis: All the water quality parameters were analyzed by standard methods [10]. The biogas generated by the three digesters was estimated by OMEGA ${ }^{\circledR}$ engineering gas-meters. Biogas composition and VFAs were measured according to Siddique and Wahid [8].

\section{RESULTS AND DISCUSSION}

$\mathrm{W}_{\mathrm{FW}}$ and $\mathrm{W}_{\mathrm{PWw}}$ were different in characteristics because of their organic matters and $\mathrm{pH}$ (Table-1). In addition, $\mathrm{W}_{\mathrm{FW}}$ had higher portions of starches and proteins than $\mathrm{W}_{\mathrm{PWw}}$. $\mathrm{W}_{\mathrm{PWW}}$ had a $\mathrm{pH}$ that was fundamentally higher than that of $\mathrm{W}_{\mathrm{FW}}$. Consequently, the option of petrochemical wastewater (PWW) to food waste $(\mathrm{FW})$ in codigestion can produce more efficient anaerobic digestion [11].

Batch experiment: The initial batch experiments were performed to assess three unique inoculum. The BMP experiment brought about methane yields of $27 \pm 5,258 \pm 6$ and 321 $\pm 8 \mathrm{~L} / \mathrm{kg}$ for $\mathrm{I}_{\mathrm{POME}}, \mathrm{I}_{\mathrm{PWw}}$ and $\mathrm{I}_{\mathrm{D}}$, respectively. The methane content in the biogas produced by $I_{D}$ was higher $(69 \pm 8 \%)$ than that of IPOME $(65 \pm 5 \%)$ and IPWW $(59 \pm 6 \%)$. Therefore, $\mathrm{I}_{\mathrm{D}}$ was chosen for the codigestion of $\mathrm{W}_{\mathrm{PWW}}$ and $\mathrm{W}_{\mathrm{FW}}$ since it produced higher methane generation.

The second arrangement of BMP experiments were led so as to assess the effect of various $\mathrm{W}_{\mathrm{PWw}}: \mathrm{W}_{\mathrm{FW}}$ proportions on anaerobic digestion interceded by $I_{D}$. The methane generation from $\mathrm{W}_{\mathrm{FW}}$ and $\mathrm{W}_{\mathrm{PWW}}$ were $13 \pm 4$ and $131 \pm 8 \mathrm{~mL} / \mathrm{g}$, respectively. The BMP experiment of $\mathrm{W}_{\mathrm{FW}}\left(\mathrm{W}_{\mathrm{FW}}: \mathrm{W}_{\mathrm{PWw}}:: 100: 0\right)$ produced lower methane. The mix of $\mathrm{W}_{\mathrm{FW}}$ and $\mathrm{W}_{\mathrm{PWw}}$ provided greater methane generation (Fig. 2). The methane yield of the codigestion in the equal proportion of $\mathrm{W}_{\mathrm{FW}}$ and $\mathrm{W}_{\mathrm{PWW}}$ improved to $321 \pm 5 \mathrm{~mL} / \mathrm{g}$ which was 2.51 times more than that of obtained from petrochemical wastewater (PWW) and 3 times more than that of food wasted (FW) when digested individually.

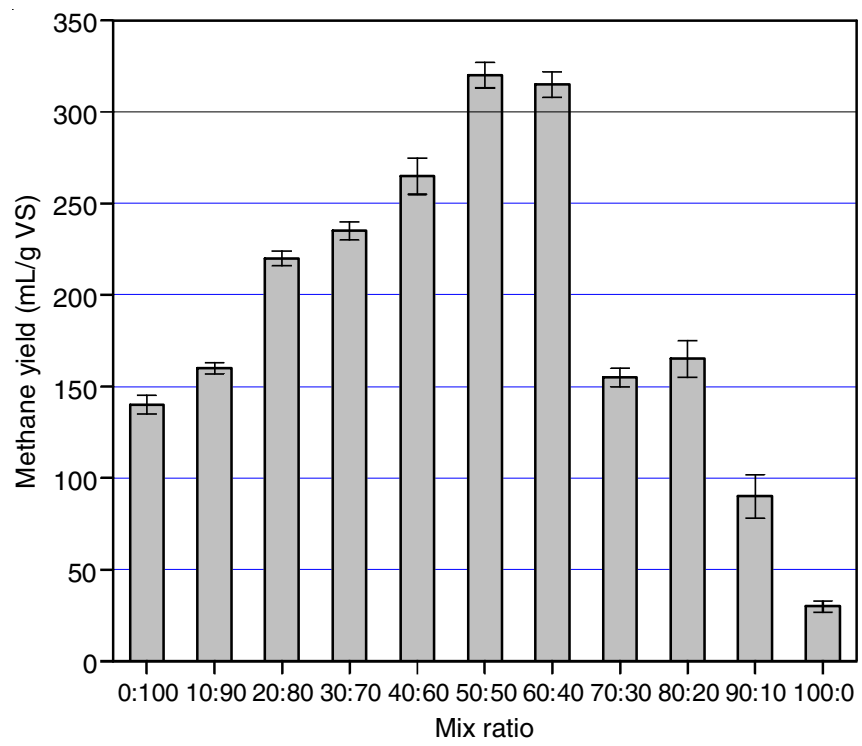

Fig. 2. Methane productions for different FW and PWW (v/v) proportion
In spite of the fact that methane yield enhanced with $\mathrm{W}_{\mathrm{FW}}$ ( $\mathrm{W}_{\mathrm{FW}}: \mathrm{W}_{\mathrm{PWw}}$ proportions of 0:100 to 50:50), $\mathrm{CH}_{4}$ generation decreased when the $\mathrm{W}_{\mathrm{FW}}$ proportion was higher than $60 \%$ (Fig. 2). Consequently, the outcomes show that codigestion appears to be significantly stronger with the enhancement of the $\mathrm{W}_{\mathrm{PWw}}$ portion and there is a limit beneath which the system turns to acidification. When $\mathrm{W}_{\mathrm{Fw}}$ portion was higher than $60 \%$, the $\mathrm{pH}$ drops beneath [6]. The enhancement of the $\mathrm{W}_{\mathrm{Fw}}$ portion up to $60 \%$ incredibly enhanced the methane generation because of the higher substance of biodegradable organics of $\mathrm{W}_{\mathrm{FW}}[12]$.

Most extreme methane generation and reduction of methane generation were estimated after roughly 20 and 50 trial days, individually. Thus, the laboratory scale methanogenic phases were calculated for HRT 21 days. The third batch experiments were completed to decide the ideal states of acidogenic period of two-phase codigestion. The $\mathrm{pH}$ of anaerobic effluent reduced only the day after the start of preliminaries by achieving $\mathrm{pH}$ of 4.5-5.0 toward the end of the analyses. The fermentation, because of formation of VFAs, caused the hindrance of methanogenic movement combined with hydrogen growth in biogas [13]. Absolute aggregation of VFAs upto $3701 \mathrm{mg} / \mathrm{L}$ was observed in the acidogenic digesters.

Biogas generation was a higher under mesophilic conditions $\left(84 \mathrm{mLH}_{2} / \mathrm{g}\right)$ than the lower heat $\left(42 \mathrm{mLH}_{2} / \mathrm{g}\right)$. These outcomes were similar with those observed by fermentative batch experiments on organic waste [9] and by persistent mode on food waste [14]. Most extreme level of VFAs and $\mathrm{H}_{2}$ content (69 \pm $5 \%$ ) was seen inside the initial 5 days; in this manner, the HRT of 6 days was connected for the acidogenic phase at mesophilic states of two-phase anaerobic digesters (Table-2).

Continuous experiments: The feed was regularly operated by combining $\mathrm{W}_{\mathrm{FW}}$ and $\mathrm{W}_{\mathrm{PWW}}$ at a volumetric proportion of half and kept at $4{ }^{\circ} \mathrm{C}$. The subsequent feed properties are listed in Table-1. The $\mathrm{pH}$ trend in the fermentation media of acidogenic and methanogenic phases of D2 and D3 were alike (Table2), while D1 demonstrated acidic state. Thus, the codigestion of food waste and petrochemical wastewater enabled the system to keep up stable $\mathrm{pH}$ at the two phases.

Both two-phase systems appeared to demonstrate better sCOD elimination contrasted than the single-phase digester (Table-2); in addition, D3 appeared to reach marginally higher sCOD elimination than D2. The sCOD elimination under the acidogenic phases for both two-phase digesters were observed to be roughly $31 \%$. The carbohydrates in the effluents was lower than $0.5 \mathrm{~g} / \mathrm{L}$, equivalent to eliminations that were constantly higher than $94 \%$ (Table-2). The VFA gathered in acidogenic phase were $6.8 \mathrm{~g} / \mathrm{L}$ and $5.9 \mathrm{~g} / \mathrm{L}$ for D2 and D3; they were then reduced by acetotrophic methanogens in the methanogenic phase. Conversely, VFAs in D1 stayed stable in the range of 1.6 and $1.99 \mathrm{~g} / \mathrm{L}$.

The level of VFA estimated in the present examination was lower than those studied by different investigations treating food waste (FW) and petrochemical wastewater (PWW) uniquely, showing that the codigestion of the two substrates enormously improved the removal of VFAs. Ghaly [15], utilized a two-phase digester at HRT of 21 days, observed VFA level more than $1.99 \mathrm{~g} / \mathrm{L}$ and lower than $0.1 \mathrm{~g} / \mathrm{L}$ for cheesy waste and cattle 
TABLE-2

DIGESTER OUTPUT FOR AFTER OPERATION $($ AVERAGE \pm SD)

\begin{tabular}{|c|c|c|c|c|c|c|c|c|c|c|}
\hline & \multicolumn{2}{|c|}{$\mathrm{pH}$} & \multicolumn{2}{|c|}{ Removal } & \multirow[b]{2}{*}{$\mathrm{CH}_{4}$} & \multirow[b]{2}{*}{$\mathrm{H}_{2}$} & \multirow[b]{2}{*}{ Biogas } & \multicolumn{2}{|c|}{ Composition } & \multirow{2}{*}{$\begin{array}{l}\mathrm{CH}_{4} \text { yielc } \\
\text { (L/kg VS }\end{array}$} \\
\hline & $\begin{array}{l}\text { Acidogenic } \\
\text { phase }\end{array}$ & $\begin{array}{l}\text { Methanogenic } \\
\text { phase }\end{array}$ & COD & $\begin{array}{c}\text { Carbogenic } \\
\text { phase }\end{array}$ & & & & $\mathrm{CH}_{4}$ & $\mathrm{H}_{2}$ & \\
\hline D1 & - & $6.8 \pm 0.4$ & $72 \pm 8$ & 97 & $0.19 \pm 0.03$ & - & 0.39 & $49 \pm 6$ & - & 121 \\
\hline D2 & $5 \pm 0.03$ & $7.9 \pm 0.5$ & $81 \pm 12$ & 99 & $0.28 \pm 0.04$ & 0.2 & 0.43 & $64 \pm 8$ & $32 \pm 4$ & 234 \\
\hline D3 & $5.2 \pm 0.04$ & $7.6 \pm 0.4$ & $84 \pm 4$ & 99 & $0.32 \pm 0.03$ & 0.03 & 0.52 & $61 \pm 7$ & 2 & 259 \\
\hline
\end{tabular}

manure individually. The methane generation rate under steady condition was commonly stable in each of the three digesters. D2 and D3 produced methane generation around $39 \%$ higher than D1 (Table-2). Also, inspite of the fact that the biogas properties of three digesters fit with in the range of anaerobic digestion of agro-industrial waste [16], the two-phase digesters performed better than the single-phase system through methane content (Table-2). It should be noted that substantial hydrogen productions were gathered from the acidogenic phase of D2 (Table 2) because of the total physical division of two phases, while the methane content was consistently underneath $4 \%$.

The methane production and methane content in the biogas were higher in two-phase digesters than in single-phase digester (Table-2). It should be noted that the methane level of $62 \%$ identified in D2 was linked with the methanogenic phase, while methane content (59\%) of D3 was estimated over the two phases. The outcomes of the continuous operation (Table-2) indicated lower methane production than those acquired in batch conditions (Fig. 2).

The greatest methane generation of $321 \mathrm{~mL} / \mathrm{g}$ volatile solid obtained in batch tests is identified with "extreme" biogas generation that is acquired with a longer digestion period (51 days) than the HRT of continuous operation. The methane production acquired in this investigation are complying $[11,17]$. The outcomes, subsequently, show a lot higher efficiency of two-phase than the single-phase one treating food waste and petrochemical wastewater in cofermentation.

\section{Conclusion}

The outcomes exhibited that the anaerobic digestion of food waste and petrochemical wastewater at half volumetric proportion gives higher methane productions than when the two substrates digested independently. In addition, the examination shows a lot higher effectiveness of two-phase process instead of single-phase process treating food waste and petrochemical wastewater in cofermentation. The two-phase concentric digester acquired a marginally higher methane generation that could be clarified by better utilization of hydrogen delivered in the acidogenic stage that could produce an enhancement of anaerobic digestion for agro-industrial substrates.

\section{ACKNOWLEDGEMENTS}

The authors are thankful to School of Ocean Engineering, Universiti Malaysia Terengganu (UMT) and Faculty of Engineering
Technology at the Universiti Malaysia Pahang (UMP) for providing the continuous access to their laboratory services. The present study was made possible by UMP RDU160315 grant.

\section{CONFLICT OF INTEREST}

The authors declare that there is no conflict of interests regarding the publication of this article.

\section{REFERENCES}

1. Å. Davidsson, C. Lövstedt, J. la Cour Jansen, C. Gruvberger and H. Aspegren, Waste Manag., 28, 986 (2008); https://doi.org/10.1016/j.wasman.2007.03.024.

2. J.C. Kabouris, U. Tezel, S.G. Pavlostathis, M. Engelmann, J. Dulaney, R.A. Gillette and A.C. Todd, Bioresour. Technol., 100, 3701 (2009); https://doi.org/10.1016/j.biortech.2009.02.024.

3. M.N.I. Siddique and Z.A. Wahid, J. Clean. Prod., 194, 359 (2018); https://doi.org/10.1016/j.jclepro.2018.05.155.

4. M.N.I. Siddique, M. Sakinah and A. Zularisam, J. Ind. Eng. Chem., 27, 44 (2015); https://doi.org/10.1016/j.jiec.2014.12.017.

5. M. Fountoulakis, I. Petousi and T. Manios, Waste Manag., 30, 1849 (2010); https://doi.org/10.1016/j.wasman.2010.04.011.

6. M.N.I. Siddique, M.S.A. Munaim and Z.B.A. Wahid, J. Clean. Prod., 145, 303 (2017);

https://doi.org/10.1016/j.jclepro.2017.01.061.

7. C.-J. Huang and X. Yang, Google Patents (2019).

8. M.N.I. Siddique and Z.B.A. Wahid, Water Environ. Res., 90, 835 (2018); https://doi.org/10.2175/106143017X15131012153031.

9. J.R. Giordano, R.J. Beetel, E.T. Wiener, J.D. Messerly, P. Malaviya, B. DiNardo and D.J. Abbott, Google Patents, 86619 P (2011).

10. American Public Health Association (APHA), Standard Methods for the Examination of Water and Wastewater, American Public Health Association: Washington, DC (2005).

11. G. Esposito, L. Frunzo, A. Giordano, F. Liotta, A. Panico and F. Pirozzi, Rev. Envo. Sci. Bio/Tech., 11, 325 (2012); https://doi.org/10.1007/s11157-012-9277-8.

12. B. Kavacik and B. Topaloglu, Biomass Bioener, 34, 1321 (2010); https://doi.org/10.1016/j.biombioe.2010.04.006.

13. Y. Chen, J.J. Cheng and K.S. Creamer, Bioresour. Technol., 99, 4044 (2008); https://doi.org/10.1016/j.biortech.2007.01.057.

14. N. Venetsaneas, G. Antonopoulou, K. Stamatelatou, M. Kornaros and G. Lyberatos, Bioresour. Technol., 100, 3713 (2009); https://doi.org/10.1016/j.biortech.2009.01.025.

15. A.E. Ghaly, Bioresour. Technol., 58, 61 (1996); https://doi.org/10.1016/S0960-8524(96)00105-8.

16. E. Comino, V.A. Riggio and M. Rosso, Bioresour. Technol., 114, 46 (2012); https://doi.org/10.1016/j.biortech.2012.02.090.

17. I.M. Nasir, T.I. Mohd Ghazi and R. Omar, Eng. Life Sci., 12, 258 (2012); https://doi.org/10.1002/elsc.201100150. 